\title{
The human-animal relationship and its influence in our culture: the case of donkeys
}

\section{A relação homem-animal e sua influência em nossa cultura: o caso dos jumentos}

\author{
Yuri Fernandes Lima' ${ }^{1}$ (D); Patricia Tatemoto ${ }^{2}$ (D); Eduardo Santurtun'; Emily Reeves²; Zoe Raw² (D) \\ ${ }^{1}$ The Donkey Sanctuary, Mexico City, Mexico \\ ${ }^{2}$ The Donkey Sanctuary, Sidmouth, Devon, United Kingdom
}

\begin{abstract}
Donkeys (Equus asinus) face a global crisis. Their health, welfare, and even their local survival are compromised as the demand for their skins increases. Such demand for donkey skins aims to supply the ejiao industry. Ejiao is a traditional remedy made from the collagen of donkey skins. Some people believe it has medicinal properties. It is estimated that the ejiao industry currently requires approximately 4.8 million donkey skins per year. Although the future of the donkeys is still uncertain, we must guarantee a life free from suffering to the animals under our responsibility. The trade of donkey skins also undermines the cultural role of donkeys. Donkeys have developed an essential role in Brazil, especially in the Northeast region of the country, carrying on their backs construction materials, water, and food, and, as a consequence, helping people build cities in the deepest hinterland. The close relationship between people and donkeys affords donkeys a unique place in the local culture. This central importance has been recognized by Brazilian artists throughout history. We have many examples of songs, books, "cordeis" (typical Brazilian literature), poems, documentaries, movies, woodcuts, paintings, and sculptures, created to honor this important actor. Here we describe some examples of this human-donkey relationship, and its influence on our culture.
\end{abstract}

Keywords: Culture. Donkey. Ethics. Human-animal. Sustainability.

\section{RESUMO}

Os jumentos (Equus asinus) estão enfrentando uma crise global. A saúde, o bem-estar e, principalmente, a sobrevivência dos jumentos está sendo comprometida à medida que a demanda por suas peles aumenta. Essa demanda por peles de jumento visa abastecer a indústria de ejiao. Ejiao é um remédio tradicional feito de colágeno de pele de jumento. Alguns acreditam que possui propriedades medicinais. Estima-se que o setor exija aproximadamente 4,8 milhões de peles de jumento por ano. Independentemente do futuro que os jumentos terão, devemos garantir uma vida com o mínimo de dignidade aos animais sob nossa responsabilidade. A preocupação ética também inclui o papel cultural dos jumentos. Os jumentos desenvolveram um papel essencial no Brasil, especialmente na Região Nordeste do país, carregando nas costas todo o tipo de material de construção, água e comida e, como consequência, ajudando o ser humano a construir as cidades no sertão. Devido à estreita relação com os seres humanos, os jumentos também estão participando da cultura. Essa importância central foi reconhecida por vários artistas brasileiros ao longo da história. Temos muitos exemplos de músicas, livros, "cordéis" (literatura típica brasileira), poemas, documentários, filmes, xilogravuras e esculturas feitos em homenagem a esse importante ator. Aqui descrevemos alguns exemplos dessa relação humano-jumento e sua influência em nossa cultura.

Palavras-chave: Cultura. Jumento. Ética. Humano-animal. Sustentabilidade. 
Correspondence to:

Yuri Fernandes Lima

The Donkey Sanctuary

Latin America and the Caribbean Office

Avenida Universidad, 3000, Facultad de Medicina Veterinaria

y Zootecnia, Edificio 2, Universidad Nacional Autónoma de

México - UNAM, Coyoacán

CP: 04510, Ciudad de México, México

e-mail: yuri.fernandes.lima@gmail.com

Received: August 31, 2020

Approved: December 22, 2020

How to cite: Lima YF, Tatemoto P, Santurtun E, Reeves E, Raw Z. The human-animal relationship and its influence in our culture: the case of donkeys. Braz J Vet Res Anim Sci. 2021;58(special issue):e174255. https://doi.org/10.11606/ issn.1678-4456.bjvras.2021.174255

Donkeys (Equus asinus) today face a global crisis. Their health, welfare, and especially their local survival are compromised as the demand for their skins increases. Such demand for donkey skins aims to supply the ejiao industry. Ejiao is a traditional remedy made from the collagen of donkey skins. Some people believe it has medicinal properties. It is estimated that the ejiao industry currently requires approximately 4.8 million donkey skins per year (The Donkey Sanctuary, 2019). As reported by The Donkey Sanctuary (2019), the global trade in donkey skins is unsustainable, unethical, and has caused significant suffering to this animal that was not only important socioeconomically, but also in the Brazilian culture.

Donkeys have developed an essential role in Brazil, especially in the Northeast region of the country, carrying on their backs construction materials, water, and food, and, as a consequence, helping people build cities in the deepest hinterland. The close relationship between people and donkeys affords donkeys a unique place in the local culture. This central importance has been recognized by Brazilian artists throughout history. We have many examples of songs, books, "cordeis" (typical Brazilian literature), poems, documentaries, movies, woodcuts, paintings (Figures 1 and 2), and sculptures (Figure 3), created to honor this important actor.

According to Professor Sônia T. Felipe, from the Federal University of Santa Catarina, the donkey, also called "jegue" or "asno" in Brazil, is an ancient equine, and 5,000-year-old fossils have been found in Egypt (Felipe, 2018). The word "jegue" can be derived from the Hausa language, which belongs to the Afro-Asian language family (Olofsson, 2012). The word "asno" derives from the Latin "asinus".

The donkey was domesticated at least 7,000 years ago in the region now known as Iraq and was brought to Brazil by the Portuguese expedition of Martim Afonso de Souza, in 1534 (Felipe, 2018).

Bread, flour, beans, dried meat

Who carries it? Hi-ho

Bread, flour, beans, dried meat

Lemon, tangerine, papaya, watermelon

Who carries it? Hi-ho

Bread, flour, beans, dried meat

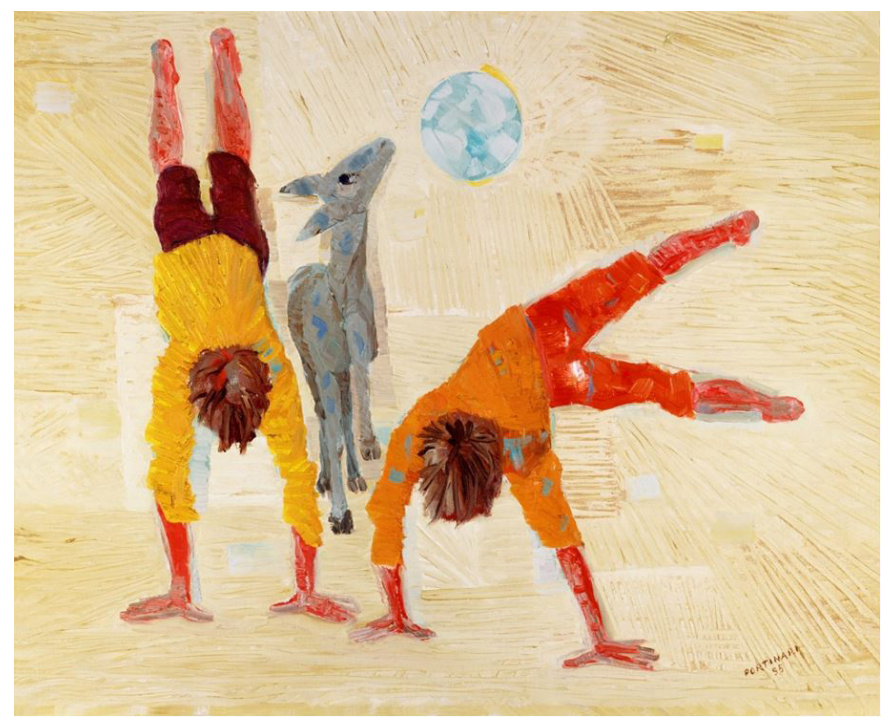

Figure 1 - "Meninos Brincando" ("Boys Playing"), 1955. Reproduction right kindly provided by João Candido Portinari.

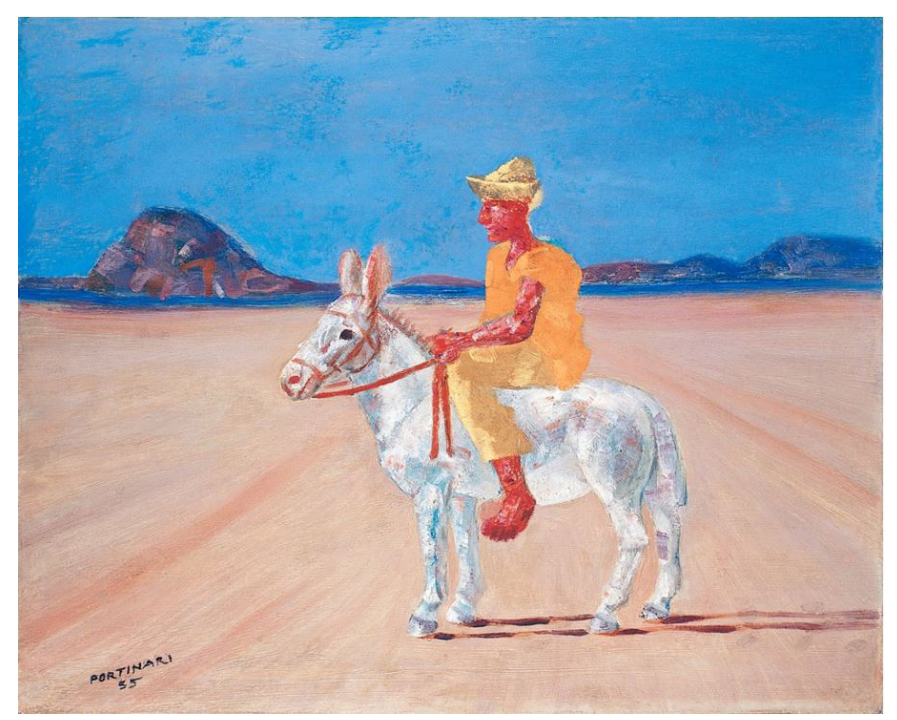

Figure 2 - "Paisagem com Retirantes" ("Landscape with Retreatants"), 1955. Reproduction right kindly provided by João Candido Portinari. 


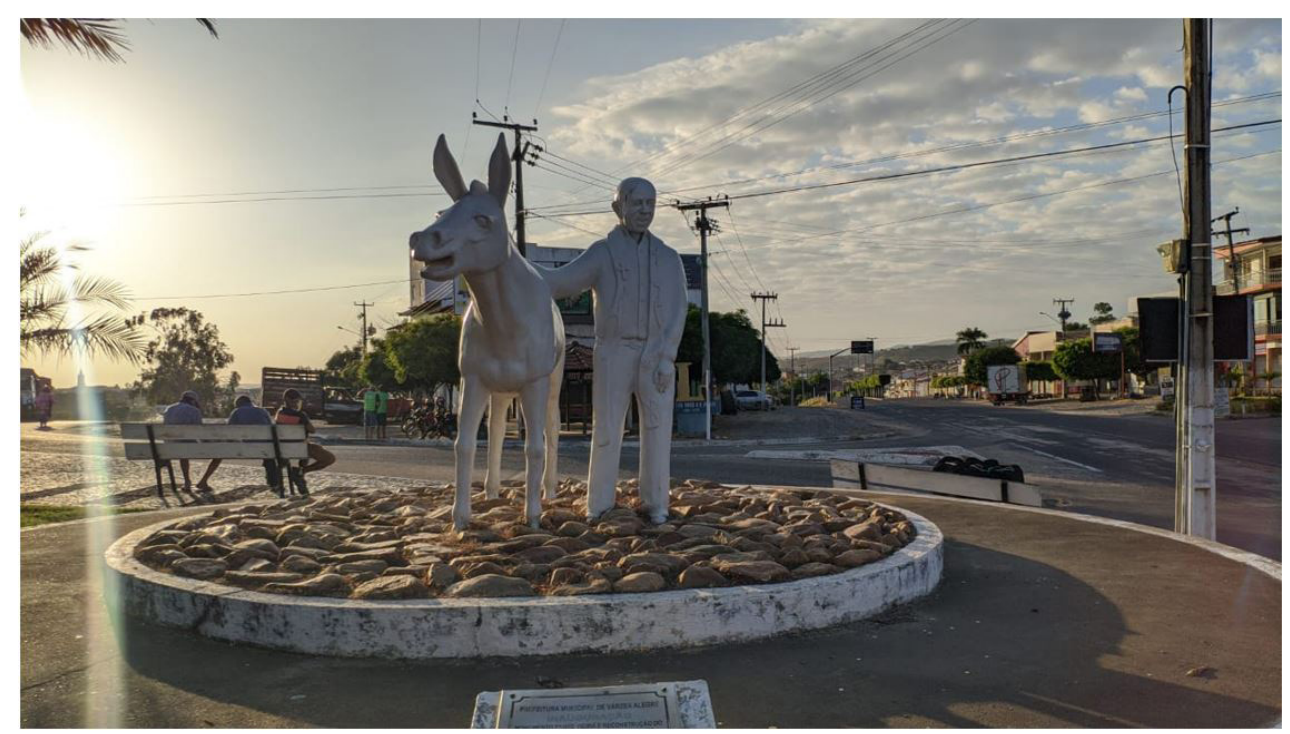

Figure 3 - Portal of the City of Várzea Alegre, in Ceará, with sculptures of Father Vieira and a donkey. The picture was kindly taken and reproduction right kindly provided by Bruno Romário Ferreira Bitu.

Lemon, tangerine, papaya, watermelon

The sand, the cement, the brick, the quarry

Who carries it? Hi-ho

(Free translation of an excerpt of the Brazilian song ("O Jumento", by Chico Buarque)

Donkeys are often recognized in song. Besides the example above (“O Jumento" - “The Donkey”, by Chico Buarque), songs recognizing the value of donkeys and the need to protect them include "Apologia ao Jumento" ("Apology to Donkey"), by Luiz Gonzaga, "Deixe o Jumento em Paz" ("Leave the Donkey Alone"), by Eline Bélier, "Jumento Celestino" ("Donkey Celestino"), by Mamonas Assassinas, and "Burro é quem mata jumento" (Stupid is that who kills donkeys"), by Adelmario Coelho.

Luiz Gonzaga do Nascimento was a Brazilian composer and singer, born in the backlands of Pernambuco, one of the northeastern states. Known as the King of "Baião" (northeast musical genre), he was considered one of the most complete, important, and creative figures in Brazilian popular music. Francisco Buarque de Hollanda, better known as Chico Buarque, is a Brazilian musician, playwright, writer, and actor. The son of Sérgio Buarque de Hollanda, an important Brazilian historian and journalist, Chico Buarque is one of the biggest names in Brazilian popular music.

Thus, it is not inconsequential that two of Brazil's greatest all-time musicians have composed songs to honor this important working animal, recognizing their historical and cultural importance.

It is true, my Lord

This history of the hinterland
Father Vieira spoke

That the donkey is our brother

\section{[...]}

The donkey has always been

The greatest developmentalist of the hinterland!

Helped the man in the daily deal

Helped the man

Helped Brazil to develop

Dragged firewood

Wood, stone, lime, cement, brick, tile

Did weir, road

He carried water to the man's house

Made the fair and served as a mount

The donkey is our brother!

And the man, in return

What does it give you?

Punishment, blow, stick in the legs, stick in the loin

Stick on the neck, stick on the face, on the ears

Ah, donkey is good, man is bad!

\section{$[\ldots]$}

But I like him

Because he is a little server who is damned!

Sacred animal!

Donkey, my brother, I recognize your worth! 
You are a patriot! You are a great Brazilian!

I am here, donkey, to recognize your worth, my brother

Now, my patriot, in the name of my hinterland

I accompany your vicar in this eternal gratitude

Accept our homage

The donkey, our brother

(Free translation of an excerpt of the Brazilian song ("Apologia ao Jumento (O Jumento É Nosso Irmão)", by Luiz Gonzaga)

Besides Carnival, other events in the Northeast projected the figure of the donkey, such as the "Jegue Dance" movement, a mixture of forró and "dance music". Genival Lacerda's song, "Rock do Jegue” (Donkey’s Rock”), played on local radios. Another song, a success in Bahia, is "Dança do Jumento", performed by Marivalda and her band Jegue Elétrico (Mota, 1995).

Cândido Portinari, one of the most important Brazilian painters of all times, painted more than 5,000 canvases, from small sketches to monumental works, such as "Guerra e Paz" panels. Among them are many paintings representing and honoring donkeys, such as the two examples below, which demonstrate that donkeys are present in the life of Brazilian people.

Besides Cândido Portinari and José Lourenço, there are many other Brazilian artists representing and honoring donkeys, including the contemporary visual artist Sérgio Amorim, from Bahia.

Also, many books address the theme of donkeys, including "O Jumento, Nosso Irmão" (“The Donkey, Our Brother"), which was written in 1964 by Antônio Batista Vieira (1964), a Brazilian priest, lawyer, economist, philosopher, teacher, writer, journalist, and politician, born in the hinterland of Ceará, state of Northeast of Brazil, and the founder of the Donkey World Club in 1996.

The world became aware of his work and actions with the book "O Jumento, Nosso Irmão", in which the author defends the donkey as an important figure in the construction of northeastern society, especially of the countryman, denouncing its slaughter, and nearextermination, for the export of meat and the production of vaccines. The book was translated into English as "The Donkey, Our Brother" and received praise from the London BBC, which considered it "[...] the most complete study to date published on the donkey" (Redação Cariri, 2019)

In the 1990s, Father Antonio Vieira launched a campaign in Ceará for the construction of the "Memorial do Jumento"
(Donkey's Memorial). He started by sending requests for support to environmental organizations, city halls, and culture departments. He intended to donate a plot of land owned by him to the construction of the memorial next to the place where he lived in Fortaleza, capital of Ceará. He commissioned an architect to design the memorial, which included a library, museum, craft store, and an office specializing in donkey diseases (Mota, 1995).

Years later, in a letter sent to former President Fernando Henrique Cardoso, Vieira asked for May $13^{\text {th }}$ to be declared the National Donkey Day, which did not happen until now. Vieira also defended the adoption of policies for the preservation of donkeys (Mota, 1995). Throughout his life, he was a great defender of donkeys.

Vieira's hometown, Várzea Alegre, in the northeastern state of Ceará, has a portal with a sculpture representing Father Vieira and a donkey. The city of Santana do Ipanema, in the northeastern state of Alagoas, also has a sculpture of a donkey in its portal. And the city of Itapetinga, in the northeastern state of Bahia, has sculptures of donkeys and the materials that they carried in the São Félix square.

Antônio Gonçalves da Silva (2011), better known as Patativa do Assaré (a city in the hinterland of Ceará), was a popular poet, composer, singer, improviser, and one of the main figures of $20^{\text {th }}$-century northeastern music. He composed the poem "Meu Caro Jumento" ("My Dear Donkey"), in which he summarized the difficulties experienced by the animal. For Patativa, the donkey was the most important animal in the world, as it carried the baby Jesus at birth (Fernandes, 2000).

The neglect, abandonment, extermination of donkeys and the use of these animals as traction, in the middle of the $21^{\text {st }}$ century, are topics addressed in the book "Sua Excelência, o Jumento" ("His Excellency, the Donkey"), authored by the president of the International Union for the Protection of Animals (Uipa) in Ceará and lawyer Geuza Leitão.

Finally, "O Padre do Jumento" (“The Father of Donkey”), written by Amorim Filho \& Duarte (1988), tells the history of Father Antonio Vieira and his above-mentioned book.

There is a specific popular literary genre in the northeast of Brazil called "Cordel literature", which originated in oral reports and was then printed on leaflets. According to the preface by João de Jesus Paes Loureiro, cordel is a poem that dialogues with very recent facts, "[...] including the poem in the context and in the extra poetic discussion of the theme"; "it is an anguished cry against the destruction of the beauty of man and nature" (Castro, 2010, pp. 09-10). 
Typical examples of cordéis on the theme of donkeys include "A Briga de Dois Matutos por causa de um Jumento" ("The Fight of Two Matutos over a Donkey"), written by Eneias Tavares dos Santos; "O Jumento que Jesus Montou" ("The Donkey that Jesus rode"), written by Marcos Mairton (2010); "Que mal o jumento fez para ser tratado assim?" ("What harm did the donkey do to be treated like this?"), written by Helonis Brandão; "Em Defesa dos Jumentos" ("In Defense of the Donkeys") written by Nivaldo CruzCredo; "O Jumento e o boi em cordel" ("Donkey and ox in cordel”), written by João Bosco Bezerra Bonfim (2013); "O Cangaceiro do futuro e o jumento espacial" ("The Cangaceiro of the future and the space donkey"), written by Klevisson Viana; "O cavalo, o camelo e o jumento" ("The horse, the camel and the donkey"), written by Carlos Alberto Fernandes da Silva; "Salopão: um Jumento do Sertão" ("Salopão: a Donkey from the Hinterland"), written by Fernando Limoeiro (2015); and "O jumento é nosso irmão" ("The donkey is our brother"), written by Sebastião Chicute.

Professor Jailson José Gomes da Rocha, from the Federal University of Paraíba, another northeast state, says that the donkey is so deeply rooted in cultural identity that has become the main figure in the documentary plot entitled "O Jegue: Patrimônio Cultural do Nordeste" ("The Donkey: Cultural Heritage of the Northeast") (Documentary / 14min / RN). This documentary presents the donkey as a living cultural heritage full of stories, poetry, disenchantment, and a character of cordel (Rocha, 2017).

There are also other documentaries and movies about donkeys including "Animais na terra da felicidade" ("Animals in the land of happiness"), and "Outros Olhares: Salve o 2 de Julho e os animais" "'Other Gazes: Save the 2nd of July and the animals"), both by Francisco Athayde, from Bahia, which discusses the fight for donkey rights, which resulted at the end of the exploitation of this animal at popular festivals in Salvador, capital of Bahia state.

Finally, "JUS: Um Filme sobre Jumentos" (“JUS: A Movie about Donkeys"), by Marcelo Dídimo, from Ceará, starts with the phrase by Afonso Arinos: “Two long ears would be better as a symbol of our nationality than the motto 'Order and Progress' inscribed on our flag." This is followed by several men from the hinterland explaining that their donkeys have history, esteem, and names. Filmmaker and researcher Rosemberg Cariry explains that donkeys are important in the economic and cultural history of the hinterland, and the universe of the imaginary as well. Hélder Máximo de Carvalho, Mayor of Várzea Alegre, says that the figure and symbolism of donkeys are an important part of the Northeast identity. Despite this, as the movie points out, history has been very cruel to donkeys, because they were first abandoned to their fate by humans and are now being slaughtered.

The great importance of the donkey in the Brazilian culture, especially in the literature, is indisputable. Major Brazilian artists have addressed the subject and dedicated time and energy to describe, honor, and register the role of donkeys in Brazil. That is why "[...] we could even say that the Donkey appears as a non-human subject essential to the development of the Brazilian historicalidentity process" (Rocha, 2017, p. 252).

It is for these reasons that the donkey should be declared as a cultural heritage by the National Historical and Artistic Heritage Institute - IPHAN. In the meantime, there is a Bill pending in the Chamber of Deputies, no. 1.218/2019, which makes the donkey a national heritage and prohibits its slaughter across the territory (Brasil, 2019).

\section{Conclusion}

Here we show many examples of the cultural influence of the human-animal relationship, specifically describing the case of donkeys in Brazil. As a working animal, donkeys helped to build entire communities across the world. This close relationship has influenced local culture to this day and the trade of donkey skins threatens not only the welfare but the survival of the species in Brazil and around the world. The global skin trade is unsustainable and unethical. In Brazil, the trade of donkey skins not only causes immense suffering, but may contribute to the loss of the donkey, an animal that was not only important socioeconomically, but also in the history and culture of Brazil.

On the other hand, it is important to mention that most of the artists mentioned here recognize the mistreatment of this animal, embodying a true paradox. This is because while donkeys are important to Brazilian history and culture, they are mistreated by humans. Donkeys were mistreated in the past, in a domestic context, and remain mistreated currently, in the donkey skin trade. The awareness of donkey welfare has a tradition in Brazilian culture that seems to contrast with the past and present ruthless exploitation of this animal. Therefore, the cultural importance of donkeys must be officially recognized.

\section{Conflict of interests}

The authors declare there is no conflict of interests. 


\section{References}

Amorim Filho LD, Duarte E. O padre do jumento. São Paulo: Cortez; 1988.

Bonfim JBB. O jumento e o boi em cordel: reconto de "As mil e uma noites”. São Paulo: Caramelo; 2013.

Brasil. Projeto de Lei no $1.218 / 2019$. Torna o jumento (Equus asinos), patrimônio nacional e pró́be o seu abate em todo o território [Internet]. Diário Oficial da União; Brasília; 2019 Feb 27 [cited 2020 June 27]. Available from: https://www.camara.leg.br/proposicoesWeb/ fichadetramitacao?idProposicao $=2193347$

Castro J. Belo Monte - o belo de destruir: literatura de cordel. Belém: Autor; 2010.

Felipe ST. Passaporte para o mundo de abolição do uso e matança de animais: jumentos. São José: Ecoânima; 2018.

Fernandes K. Preço de jumento cai no Nordeste [Internet]. Folha de São Paulo; 2000 Oct 27 [cited 2020 June 27]. Available from: https:/www1.folha.uol.com.br/fsp/cotidian/ ff2710200019.htm

Limoeiro F. Salopão: um jumento do sertão. Belo Horizonte: Aletria; 2015.

Mairton M. O jumento que Jesus montou - seguido de uma visita inesperada: literatura de cordel. Brasília: Ensinamento; 2010.

Mota P. Padre faz campanha pelo jegue [Internet]. Folha de São Paulo; 1995 Mar 20 [cited 2020 June 27]. Available from: https://www1.folha.uol.com.br/fsp/1995/3/20/ cotidiano/1.html

Olofsson V. As palavras de origem africana em $O$ sumiço da Santa de Jorge Amado [thesis]. Stockholm: Department of Spanish, Portuguese and Latin American Studies, Faculty of Humanities, Stockholm University; 2012 [cited 2020 June 25]. Available from: https://www.diva-portal.org/smash/ record.jsf?pid=diva2:623888

Redação Cariri. Nosso irmão, o jumento. Revista Cariri; 2019 Dec 2 [cited 2020 June 27]. Available from: https:// caririrevista.com.br/nosso-irmao-o-jumento/

Rocha JJG. O abate de Jumentos em Miguel Calmon-BA. In: Araujo AR, Belchior GPN, Gordilho HJS, Viegas TES, editors. A proteção da sociobiodiversidade na mata atlântica e na caatinga. 1. ed. São Paulo: Instituto O Direito por um Planeta Verde; 2017. p. 248-266.

Silva CAF. O cavalo, o camelo e o jumento. São Paulo: Luzeiro; 2011.

The Donkey Sanctuary. Under the skin: update on the global crisis for donkeys and the people who depend on them [Internet]. 2019 [cited 2020 Aug 27]. Available from: https:// www.thedonkeysanctuary.org.uk/sites/uk/files/2019-12/ under-the-skin-report-english-revised-2019.pdf

Vieira AB. O jumento, nosso irmão. Rio de Janeiro: Livraria Freitas Bastos; 1964.

Financial Support: None. 